\title{
Genetic control of resistance on Mangifera indica to Ceratocystis wilt
}

\author{
Daniele Aparecida Alvarenga Arriel ${ }^{a}$, Lúcio Mauro da Silva Guimarães ${ }^{\mathrm{b}}$, \\ Marcos Deon Vilela de Resende ${ }^{c}$, Francisco Pinheiro Lima Neto ${ }^{d}$, \\ Daniella Flávia Said Heid Schettini Silva ${ }^{\mathrm{b}}$, Dalmo Lopes de Siqueira ${ }^{\mathrm{e}}$, \\ Acelino Couto Alfenas ${ }^{\mathrm{b}, *}$ \\ a Graduate Program in Genetics and Breeding, Universidade Federal de Viçosa, 36570-900, Viçosa, MG, Brazil \\ b Department of Plant Pathology, Universidade Federal de Viçosa, 36570-900,Viçosa, MG, Brazil \\ c Embrapa Florestas/Universidade Federal de Viçosa, Estrada da Ribeira, Km 111, 83411-000 Colombo, PR, Brazil \\ d Embrapa Semiárido, Rodovia BR-428, Km 152, 56302-970 Petrolina, PE, Brazil \\ e Department of Plant Science, Universidade Federal de Viçosa, Brazil
}

\section{A R T I C L E I N F O}

\section{Article history:}

Received 23 May 2016

Received in revised form 12 August 2016

Accepted 1 September 2016

Available online 16 September 2016

\section{Keywords:}

Mango

Ceratocystis

Breeding

Inheritance

"Seca-da-mangueira"

Mango decline

\begin{abstract}
A B S T R A C T
Ceratocystis wilt, caused by Ceratocystis fimbriata is one of the most serious limiting factors for mango production in Brazil. Despite efforts in the selection and the identification of mango cultivars resistant to Ceratocystis wilt, the genetic basis of the resistance remains unknown. Therefore, the objective of this study was to understand the inheritance of resistance to $C$. fimbriata by artificial inoculations of the pathogen in progenies of six commercial varieties of mango using "Tommy Atkins" as the male parent. The cultivars "Keitt", "Palmer", "Tommy Atkins" and "Van Dyke” were confirmed as moderately resistant, whereas "Coquinho", "Espada" and "Haden" were susceptible. The results of the inoculation on the progenies of these cultivars revealed that the resistance in mango is polygenic with a prevalence of genes expressing the effects of dominance and epistasis. The genetic gain with the selection of the 10 more resistant plants was $46 \%$, which indicated a $46 \%$ reduction in disease severity. In general, a low frequency of the alleles favorable to disease resistance was observed in the population studied, which suggests the need for the introduction of new sources of genetic materials carrying the genes responsible for resistance.
\end{abstract}

(C) 2016 Elsevier B.V. All rights reserved.

\section{Introduction}

The mango (Mangifera indica L.) is one of the most consumed tropical fruits in the world (FAO, 2013). Native to Asia, the mango was initially dispersed by the Portuguese navigators in 1600 in Africa and subsequently in Brazil (Mukherjee, 1972; Mukherjee and Litz, 2009). At present, the mango is globally cultivated in most tropical and subtropical countries. India is the world's largest mango producer, with an output of about 18 million tons per year (FAO, 2013). Brazil is the seventh largest producer in the world with the crop cultivation being concentrated in the region of the "Vale do São Francisco", in the states of Bahia and Pernambuco, and in the southeast of the country in the states of Minas Gerais and São Paulo (Brazilian Fruit Yeakbook, 2014). Currently, cultivars originating from Florida (USA) such as "Haden”, “Keitt”, “Kent”, "Palmer”, “Van

\footnotetext{
* Corresponding author.

E-mail address: aalfenas@ufv.br (A.C. Alfenas).
}

Dyke" and, especially, "Tommy Atkins", are the most planted in Brazil and in other western countries (Carvalho et al., 2004; Knight et al., 2009). Brazilian cultivars such as Coquinho, Rosa, Ubá, and Espada are also extensively cultivated in Brazil. "Espada" is widely planted in northeastern Brazil for fresh fruit consumption and as rootstock. The "Ubá" is mainly used for juice production, especially in the Zona da Mata of the Minas Gerais state (Rocha et al., 2014).

Ceratocystis wilt, caused by Ceratocystis fimbriata, Ellis \& Halsted is one of the main limiting factors for mango production in Brazil. Ceratocystis wilt, also termed "Seca da Mangueira", "Mal do Recife" or "Mango Decline", was first described in Recife, Pernambuco. At that time, the causal agent was attributed to Diplodia recifensis (Carvalho, 1938), and later,to Ceratocystis fimbriata (Viegas, 1960). By the end of the 1990's, this disease was reported for the first time outside Brazil, in the Middle East, in Oman, and subsequently in Pakistan (Al-Adawi et al., 2003; Malik et al., 2005) becoming a disease of international concern.

The disease symptoms can vary according to the local of infection in the plant. If the infection occurs on branches, the main 
symptoms are wilting of the affected branches, followed by foliage drying and gum exudation in the trunk. If the infection occurs through the roots, wilting and sudden death of the plant are observed. In both cases, the xylem discoloration occurs as consequence of the pathogen infection (Ploetz and Freeman, 2009; Viegas, 1960). The pathogen is disseminated by infected rootstock or grafted plants, contaminated pruning tools and insects such as Hypocryphalus mangiferae and coleoborers of the Xyleborus genera, also known as Ambrosia beetles (Al Adawi et al., 2006; Masood et al., 2008; Rossetto and Ribeiro, 1983; Souza et al., 2013; Van Wyk et al., 2007). Aspects of the disease such as the easy dissemination of the fungus in the orchard, the wide host range of $C$. fimbriata, the survival of the fungal structures in the soil and the colonization of vascular system of the plants make disease management difficult. Eradication of the infected plants and branches exhibiting disease symptoms and mainly the planting of resistant genotypes are the most suitable measures of control.

Genetic variability for resistance to Ceratocystis wilt has already been observed in differents cultivars of mango used as scions or rootstocks (Galli et al., 2011; Ribeiro et al., 1984; Rossetto et al., 1996). According to these studies, "Haden" is considered highly susceptible. Among the moderately resistant are "Tommy Atkins" and "Kent". On the other hand "Manilla" ("Carabao") and "Mangad'água" are resistant (Galli et al., 2011). Because of this genetic variability, efforts have been taken to select and identify resistant cultivars. However, the genetic basis of resistance to Ceratocystis wilt in mango remains unknown. This information is fundamental to support and guide the breeding programs in the development of new commercial resistant cultivars. Therefore, in this work, we evaluated the genetic basis of resistance to Ceratocystis wilt by artificial inoculation of the pathogen in scions of "Tommy Atkins", "Coquinho", "Espada", "Haden", "Keitt”, "Palmer" and "Van Dyke" and their progenies using "Tommy Atkins" as the pollen donor.

\section{Material and methods}

\subsection{Plant material}

A total of 197 mango genotypes derived from six full-sib families provided by the Breeding Program of Mango of the Empresa Brasileira de Pesquisa Agropecuário (Embrapa)- Semiárido, were evaluated (Table 1). The Tommy Atkins cultivar was utilized as the male parent for all the crossings. The Brazilian cultivars Coquinho and Espada and the American cultivars Haden, Keitt, Palmer and Van Dyke were used as the female parents. All plants of the six families were genotyped using microsatellite markers to confirm their hybrid nature (Arriel, 2015). Only plants with confirmed paternity were used in the study.

The progenies were obtained through open pollination, where each female parent was identified in the middle of an orchard of the T. Atkins cultivar. The fruits from the female parents

\section{Table 1}

Number of individuals progeny per family and the average family severity of stem wilt symptoms 60 days after inoculation with Ceratocystis fimbriata in the six families studied. Percentage of disease severity was calculated by dividing the lesion length $(\mathrm{cm})$ by plant height from the grafting point $(\mathrm{cm})$ and then multiplying by 100.

\begin{tabular}{lll}
\hline Family $\left(q \times \sigma^{7}\right)$ & $\begin{array}{l}\text { Number of progeny } \\
\text { per family }\end{array}$ & $\begin{array}{l}\text { Family average } \\
\text { severity (\%) }\end{array}$ \\
\hline Coquinho x Tommy Atkins & 16 & 72.808 \\
Espada x Tommy Atkins & 13 & 60.411 \\
Haden x Tommy Atkins & 47 & 65.791 \\
Keitt x Tommy Atkins & 47 & 56.552 \\
Palmer x Tommy Atkins & 33 & 64.146 \\
Van Dyke x Tommy Atkins & 41 & 61.206 \\
Overall average & & 63.486 \\
\hline
\end{tabular}

were harvested and transported to the experimental campus of Embrapa-Semiárido for seedling production and subsequent planting in the field at a spacing of $4 \times 4 \mathrm{~m}$. The plants were microaspersion irrigated and fertilized as required based on the soil analysis.

To evaluate the resistance of the progenies, each plant was multiplied, by grafting, to obtain clonal replicates. "Imbu", susceptible to Ceratocystis wilt (Oliveira et al., 2016), served as rootstock. The number of individuals per family (Table 1 ) as well as the number of clonal replicates per plant varied due to differences in the number of plants obtained in each cross, due to differences in the number of plants that had their paternity confirmed by microsatellite markers and because there was variation in the survival of the grafted plants. However, in the majority of the analyzed genotypes (91\%), the number of plants per genotype was equal to or greater than three.

\subsection{Inoculations}

The isolate of $C$. fimbriata SPMA3 from the culture collection of the Forest Pathology Laboratory (UFV/Viçosa, MG), obtained from infected host tissue of "Palmer" in Monte Alto, São Paulo, was used. This isolate was selected for its high degree of sporulation in culture and its high aggressiveness in a broad spectrum of mango cultivars (Oliveira et al., 2016). The identity of the isolate was confirmed by sequencing ITS, $\beta$-tubulin, TEF- $1 \alpha$ and mating type gene regions of DNA and subsequent comparison with other sequences of $C$. fimbriata (Oliveira et al., 2015a).

For inoculation, the bark replacement method was employed (Alfenas et al., 1983). The fungus was grown in V8-AM medium (Brito et al., 2014), at $28^{\circ} \mathrm{C}$ in a 12 -h photoperiod for ten days. Subsequently, a $6.4 \mathrm{~mm}$ disk of bark was removed at about $6 \mathrm{~cm}$ above the grafting point, and replaced by an inoculum plug of the same size taken removed from the edges of an active growing colony. After inoculation, the wound was covered with PVC plastic to prevent contamination and dehydration. Plants of the cultivar Espada were used as the susceptible comparator (Ribeiro et al., 1986; Araújo et al., 2014). Ten plants treated equally with medium plug without fungus were used as the control. The plants were incubated in a greenhouse where the average daily temperature and humidity were $26^{\circ} \mathrm{C}\left(17-36^{\circ} \mathrm{C}\right)$ and $80.8 \%$ (46-95\%), respectively. After 60 days, the inoculated plants were sectioned longitudinally and the length of xylem discoloration above and below the point of inoculation was measured. Disease severity was calculated by dividing the lesion length $(\mathrm{cm})$ by plant height from the grafting point (cm) and then multiplying by 100 (Oliveira et al., 2015b).

\subsection{Statistical and genetic analysis}

The Dunnett test $(p \leq 0.05)$ was used to classify the parents with respect to disease susceptibility using the STATISTICA 12.0 software (StatSoft). The estimates of the variance components and genetic parameters were obtained by the mixed models method via the REML (Restricted maximum likelihood)/BLUP (Best linear non-biased prediction) procedure (Resende, 2007) using the Selegen-RemL/Blup software (Resende, 2002). The RemL/Blup adjustment was based on the following mixed model:

$\mathrm{y}=\mathrm{Xr}+\mathrm{Zf}+\mathrm{Sc}+\mathrm{e}$,

in which, $y$ is the vector of data, $r$ is the vector of fixed effects (replicates) added to the general average, $f$ is the vector of the effects of families of full sibs (random), $c$ is the vector of individuals effects within family of full sibs (random), and $e$ is the vector of errors (random). The capital letters represent the incidence matrices for the referred effects. 


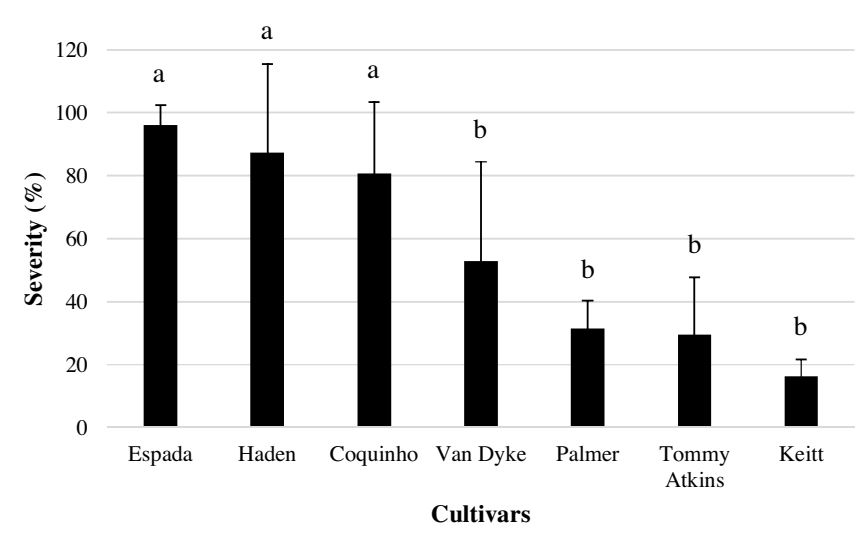

Fig. 1. Severity on mango cultivars at 60 days after inoculation with Ceratocystis fimbriata. Cultivars followed by the same letters do not differ by Dunnett test $(\mathrm{p} \leq 0.05$ ). Cultivar "Espada" was used as the susceptible control. Percentage of disease severity was calculated by dividing the lesion length $(\mathrm{cm})$ by plant height from the grafting point $(\mathrm{cm})$ and then multiplying by 100 .

The variance components associated with the model can be decomposed as follows:

Total genetic variance among full-sib families (Vfam)

$V f a m=(1 / 2) \sigma_{a}^{2}+(1 / 4) \sigma_{d}^{2}$

Total genetic variance among individuals within families (Vindividual/fam)

Vindividual $/ \mathrm{fam}=(1 / 2) \sigma_{a}^{2}+(3 / 4) \sigma_{d}^{2}+\sigma_{i e}^{2}$

The total heritability $\left(h_{g}^{2}\right)$ is given by

$h_{g}^{2}=\frac{V f a m+\text { Vindividual } / \text { fam }}{V f}$,in which:

$\sigma_{a}^{2}$ : Additive genetic variance

$\sigma_{d}^{2}$ : Dominance genetic variance

$\sigma_{i e}^{2}$ : Epistatic interactions genetic variance

Vf: Phenotypic variance

The significance of the model's effects was tested by deviance analysis using the likelihood ratio test (LTR), by which the significance was evaluated using the chi-square test with one degree of freedom at $1 \%$ and $5 \%$ probability of error type I. This type of analysis is indicated in the cases of models with unbalanced data (Resende, 2007).

The genetic gain with the selection of the top 10 most resistant plants was also estimated. The genotypic values were estimated taking into account the information of individuals and families.

\section{Results}

The cultivars (Fig. 1) and their progenies (Fig. 2) varied in resistance. Bark lesions and xylem discoloration varied among the inoculated plants. Highly susceptible genotypes revealed wilt symptoms and subsequently died (Fig. 3). In general, the lesions progressed upwards. The fungus was re-isolated from the inoculated plants. Non-inoculated plants did not exhibit any disease symptoms.

Among the parents studied, "Keitt" was the most resistant with an average of $16.2 \%$ of disease severity and "Espada" was the most susceptible with $96.1 \%$ (Fig. 1). Although all the cultivars tested were susceptible, the disease was less severe in "Palmer", "Tommy Atkins", "Van Dyke" and "Keitt" and they were included in the same group by the Dunnett test at 5\%. "Espada", "Coquinho" and "Haden" were the most susceptible and were grouped separately from the other cultivars (Fig. 1).

All families studied segregated for resistance (Fig. 2). However, none of them revealed a genotypic average lower than that pre-
Table 2

Analysis of Deviance by the likelihood ratio test(LTR) indicating the genotypic effects of family and individuals within families.

\begin{tabular}{lll}
\hline Effect & Deviance $^{\mathrm{a}}$ & LTR \\
\hline Family & 7882.85 & $4.4^{\mathrm{b}}$ \\
Individual effects within Family & 8036.81 & $164.36^{\mathrm{c}}$ \\
Full model & 7878.45 & \\
\hline
\end{tabular}

a Deviance the fitted model without the corresponding effect

b Significant by chi-square test at $5 \%(3,84)$ and $1 \%(6,63)$ respectively.

c Significant by chi-square test at $5 \%(3,84)$ and $1 \%(6,63)$ respectively.

sented by the most resistant cultivar Keitt, or higher than that presented by the most susceptible cultivar, Espada (Fig. 1). Overall, the average of all crossings was close to the overall population average (Table 1). For all crossings, the individuals with genotypic values of severity out of the range of their parents were observed (Fig. 2), which indicates the occurrence of transgressive segregation.

The genotypic effects of individuals within families were significant for the deviance analysis $(p \leq 0.01)$. For the families, the genotypic effects were smaller, but still significant $(p \leq 0.05)$ (Table 2). The relative coefficient of variation of 0.25 (Table 3 ) indicated a high environmental variance in the total variation. However, because of the great number of replicates, the estimated accuracy values were high (>0.70) (Table 3) (Resende and Duarte, 2007) which indicate good precision and experimental quality. The estimated total heritability (or broad-sense heritability) was 0.37 , considered moderate to high magnitude. The heritability of individuals within families was 33\%, whereas the heritability between families was $3.7 \%$ (Table 3 ).

The estimation of the variance components in full-sib families and individuals within families did not allow for separation of the additive effects from effects of dominance and epistasis. However, when assessing the magnitude of the heritability values between and within families and the composition of the genetic variances involved in their estimation, we concluded that effects of dominance and epistasis contributed more greatly to character expression than did the additive effects. (See Section 2.3: "Statistical and genetic analysis" and the expressions for the estimation of variance among the full-sib families and variance among the individuals within the families). The estimates of genetic variance between the full-sib families were much higher than those obtained within the full-sib families. The magnitude of the additive variances involved in the estimation of variance between and within families is the same $\left(1 / 2 \sigma_{a}^{2}\right)$. That is, they contribute equally to the total variance in both situations (between and within families). In turn, the variances due to the dominance deviations have a much greater contribution between families $\left(3 / 4 \sigma_{d}^{2}\right)$ than within families $\left(1 / 4 \sigma_{d}^{2}\right)$, and the variances due to the epistatic effects are present only in the estimation of the variance between families. Thus, it can be concluded that the greater the magnitudes of variance among families compared with that within families are associated with the occurrence of epistatic effects and dominance.

The genetic gain obtained with the selection of the 10 most resistant plants, was $46 \%$, which implied $46 \%$ reduction in disease severity (Table 4).

\section{Discussion}

This study aimed to elucidate the genetic control of the resistance to Ceratocystis wilt on mango. From the results of the present study, the methods employed for inoculation and disease evaluation were found to be appropriate to assess the resistance to Ceratocystis wilt in different materials once they allowed for the expression of a considerable genotypic variability. This variability 

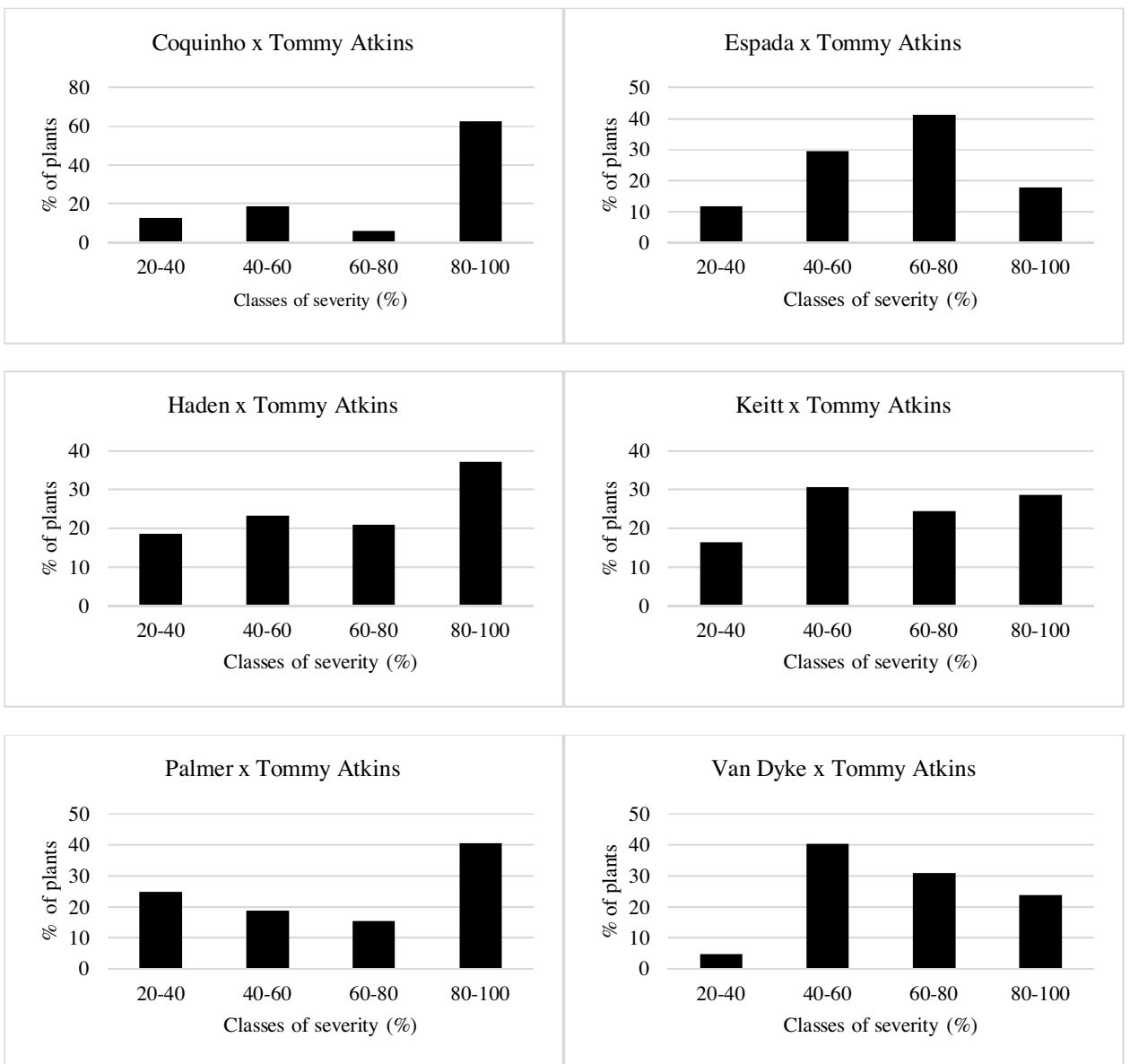

Fig. 2. Frequency distribution based on classes of severity at 60 days after inoculation with Ceratocystis fimbriata for the six families of Mangifera indica evaluated.

Table 3

Estimates of genetic parameters for resistance to Ceratocystis wilt in Mangifera indica based on the percentage of lesion size on the branch.

\begin{tabular}{ll}
\hline Genetic parameters & Values \\
\hline Total genetic variance among full-sib families & 44.83 \\
Total genetic variance among individual within families & 401.14 \\
Environmental variance & 761.37 \\
Individual phenotypic variance & 1207.33 \\
Heritability between full-sib families & $0.037 \pm 0.017$ \\
Heritability of individuals within family & 0.33 \\
Individual heritability in the broad sense & 0.37 \\
Coeficient of genotypic variation (CVg in\%) & 10.55 \\
Coeficient of residual variation (CVe in\%) & 43.45 \\
Relative coefficient of variation & 0.25 \\
Accuracy of family selection & 0.70 a 0.79 \\
Accuracy of potencial cultivars selection & 0.71 a 0.91 \\
Average & 63.48
\end{tabular}

associated with high values of accuracy permitted the discrimination between highly susceptible and resistant mango genotypes. The heritability values found associated with the high environmental influence indicated that the inheritance of resistance in mango to Ceratocystis wilt is polygenic. Additionally, the larger magnitudes of non-additive genetic effects compared with the additive effects also indicated that genes with effects of dominance and epistatic interaction are mainly involved in the trait control.

The genetic inheritance of most agronomic traits in mango has not yet been determined probably because of the long juvenile phase of the plant, high heterozygosity, polyembryony, high natural fruit shedding, cultivar incompatibility and small population size (Bally et al., 2009; Iyer and Schnell, 2009). Although we have studied a limited number of families and plants/family, the identification of hybrids by microsatellite markers of the progenies studied ensured accurate statistical analysis of the data (Arriel, 2015). In addttion, the high estimated values of selective accuracy (Resende and Duarte, 2007) indicated confidence in the estimation of genetic values and, therefore, security in the selection (Resende, 2002).

This is the first study to explain the inheritance model of Ceratocystis wilt resistance in $M$. indica. However, the genetic control of resistance has been reported earlier in other pathosystems involving Ceratocystis and tree species. Brawner et al. (2015) evaluated the inheritance of resistance of Acacia mangium to C. fimbriata (sin. C. acaciivora $=C$. manginecans $=C$. mangicola $=C$. mangivora). Similar to the results of this study, these authors found that non-additive effects prevail in the resistance to the fungus as well as low magnitudes of narrow-sense heritability (0.06). However, Rosado et al. (2010) studied the genetic parameters involved in the resistance to C. fimbriata in interspecific progenies of Eucalyptus grandis and E. urophylla and found values of broad and narrow-sense heritability of 0.59 and 0.50 , respectively. These authors showed that there is a strong additive genetic control involved in the resistance to this disease in Eucalyptus. The results of these studies showed that, overall, the inheritance of resistance to Ceratocystis wilt is a quantitative trait, but the allelic interactions vary with the host species. Furthermore, the results reported by Rosado et al. (2010) indicate that for Eucalyptus, the use of families derived from crossings between different species allowed for an increase in the number of alleles favorable to resistance and greater heritability values. Identification of new sources of resistance from other Mangifera species need to be evaluated and introduced in future crossings to increase 

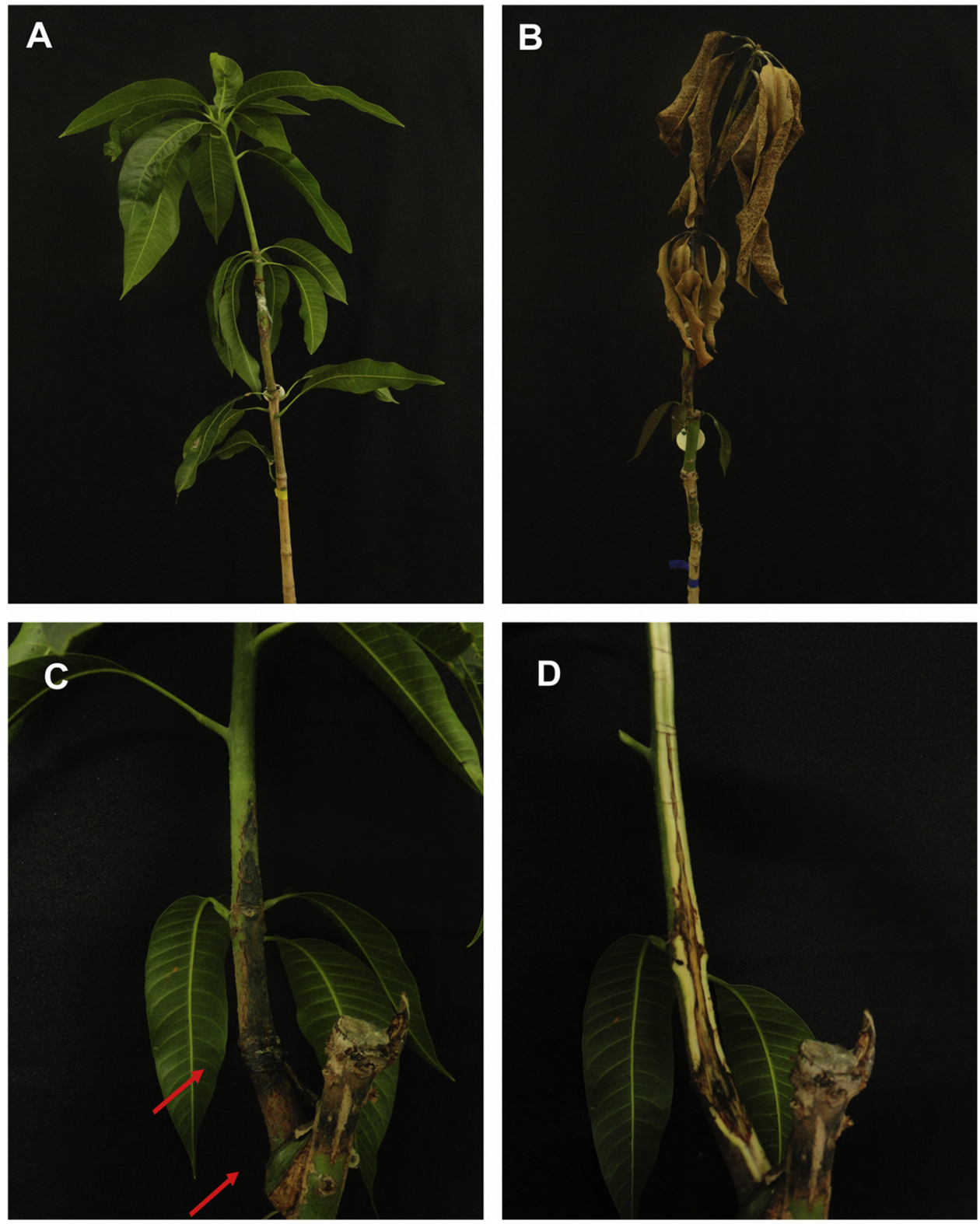

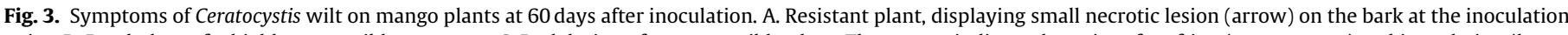

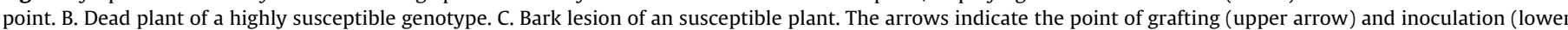
arrow). D. Xylem discoloration of an S plant.

the genetic variability and support breeding programs for disease resistance and other traits.

The low heritability values among families, associated with discrete gains, did not allow for the selection of a family whose effects greatly contributed to disease resistance. Similar results were reported by Brawner et al. (2015) and Roux et al. (2000) for Ceratocystis wilt resistance in Acacia spp. In our studies, all families revealed highly susceptible individuals indicating the existence of alleles unfavorable to resistance in the parents tested. In fact, all the cultivars used in this study were susceptible, but they differed in disease intensity. These results lead us to conclude that the alleles controlling resistance to this disease are relatively rare in the population studied. This associated with allelic interactions of dominance and epistasis hindered the production of a greater number of resistant individuals in these families. On the other hand, the highest heritability values among individuals within families indicated the feasibility of selection and genetic gains in the selection of more resistant individuals in the population.
The low frequency of alleles controlling resistance in the progenies studied and the small effect of families are possibly related to the parentage of some of the genitors used (Schnell et al., 2006). Pedigree studies by microsatellite markers indicate that the cultivars "Tommy Atkins", "Palmer" and "Van Dyke" are possibly derivates from "Haden" (Schnell et al., 2006), which is highly susceptible to Ceratocystis wilt. Thus, the relative resistance found in "Tommy Atkins" "Palmer" and "Van Dyke" had probably originated from an unknown parent, crossed with "Haden". Besides, "Coquinho" and "Espada", although not related to the Florida cultivars, are very susceptible to the disease, which did not favor the presence of alleles for resistance in their progenies.

Excepting "Palmer", the lower susceptibility of "Keitt", "T. Atkins" and "Van Dyke" observed in this study was also reported earlier (Araújo et al., 2014; Galli et al., 2011; Ribeiro et al., 1984, 1986; Rossetto et al., 1996). Nevertheless, a high physiological variability in aggressiveness has been reported in $C$. fimbriata populations from mango and other crops (Araújo et al., 2014; Nunes, 
Table 4

Genetic gain based in reduction on the percentage of lesion size on the branch for resistance to Ceratocystis wilt with the selection of the top 10 potential cultivars.

\begin{tabular}{|c|c|c|c|c|c|}
\hline Family & Individual progeny code & $\begin{array}{l}\text { Genotypic effect below } \\
\text { average }\end{array}$ & Genotypic value & $\begin{array}{l}\text { Accuracy for the selection of } \\
\text { potential cultivars }\end{array}$ & Genetic gain (\%) \\
\hline Keitt x Tommy Atkins & KT22 & -38.8390 & 24.6467 & 0.81 & -61.18 \\
\hline Keitt x Tommy Atkins & KT52 & -38.0126 & 25.4731 & 0.81 & -59.88 \\
\hline Keitt x Tommy Atkins & KT94 & -35.5517 & 27.9340 & 0.86 & -56.00 \\
\hline Palmer x Tommy Atkins & РT26A4 & -34.9163 & 28.5695 & 0.82 & -55.00 \\
\hline Palmer x Tommy Atkins & PT11A5 & -33.9431 & 29.5427 & 0.88 & -53.47 \\
\hline Keitt x Tommy Atkins & KT31 & -32.7547 & 30.7310 & 0.77 & -51.59 \\
\hline Keitt x Tommy Atkins & KET5A7 & -30.8808 & 32.6050 & 0.86 & -48.64 \\
\hline Van Dyke x Tommy Atkins & VT72 & -30.1311 & 33.3546 & 0.77 & -47.46 \\
\hline Van Dyke x Tommy Atkins & VT59 & -30.0833 & 33.4025 & 0.86 & -47.39 \\
\hline Keitt x Tommy Atkins & KET4A7 & -29.0753 & 34.4104 & 0.87 & -45.80 \\
\hline
\end{tabular}

2015; Oliveira et al., 2015b, 2016; Rossetto et al., 1996). Thus, the fungal isolate used in our study is highly aggressive to different mango cultivars and sporulates well in culture medium (Oliveira et al., 2016). However, extrapolating our results to other isolates is uncertain and requires experimental verification.

In our study, we used "Imbu" as rootstock of all plants tested due to availability of seedlings. Although this cultivar is susceptible to the disease, Oliveira et al. (2016) used this same approach to evaluated, the disease severity of different mango cultivars grafted on "Espada" also highly susceptible to disease. As in our experiment, these authors identified different levels of severity in individuals assessed (scions) what indicates that the susceptibility of the rootstock did not influence the disease expression.

The greatest magnitudes of the non-additive effects controlling resistance to Ceratocystis wilt in $M$. indica suggest that the search for resistance should be conducted in controlled crossings between genetically divergent cultivars. The resistant genotypes should be multiplied clonally and their resistance validated against different isolates of the pathogen. However, the low frequency of alleles favorable to disease resistance in the materials studied and the low genetic diversity among the main mango cultivars grown in Brazil indicate the need for the introduction of new genetic materials to expand the genetic basis of this crop. Sources from other species or varieties of Mangifera may favor the development of new commercial varieties resistant to Ceratocystis wilt and suitable for the market.

\section{Acknowledgments}

This work was supported by Vale, CNPq and Capes. The authors would also like to thank Paulo Juscinei Moreira, Angélica Nunes as well as employees of the Embrapa Semiárido and Clonar Resistência a Doenças for their technical assistance.

\section{References}

Al Adawi, A.O., Deadman, M.L., Al-Rawahi, A.K., Al-Maqbali, Y.M., Al-Jahwari, A.A., Al-Saadi, B.A., Al Amri, I.S., Wingfield, M.J., 2006. Aetiology and causal agents of mango sudden decline disease in the Sultanate of Oman. Eur. J. Plant Pathol. 116 (4), 247-254.

Al-Adawi, A.O., Deadman, M.L., Al-Rawahi, A.K., Khan, A.J., Al Maqbali, Y.M., 2003. Diplodia theobromae associated with sudden decline of mango in the Sultanate of Oman. Plant Pathol. 52 (3), 419.

Alfenas, A.C., Jeng, R., Hubbes, M., 1983. Virulence of Cryphonectria cubensis on Eucalyptus species differing in resistance. Eur. J. For. Pathol. 13 (4), 197-205.

Araújo, L., Silva Bispo, W.M., Cacique, I.S., Cruz, M.F.A., Rodrigues, F.A., 2014. Histopathological aspects of mango resistance to the infection process of Ceratocystis fimbriata. Plant Pathol. 63 (6), 1282-1295.

Arriel, D.A.A., 2015. Caracterização molecular de híbridos obtidos via cruzamentos naturais e controle genético da resistência à murcha-de-ceratocystis em Mangifera indica. Tese de doutorado, Universidade Federal de Viçosa, Brasil, pp. 52 .

Bally, I.S.E., Lu, P., Johnson, P.R., 2009. Mango breeding. In: Jain, S.M., Priyadarshan, P.M. (Eds.), Breeding Plantation Tree Crops: Tropical Species. Springer, New York, pp. 51-82.
Brawner, J., Japaridin, Y., Lapammu, M., Rauf, R., Boden, D., Wingfield, M.J., 2015. Evaluating the inheritance of Ceratocystis acaccivora symptom expression in a diverse Acacia mangium breeding population. South For. 77 (1), 83-90.

Brazilian Fruit Yeakbook 2014. Santa Cruz do Sul: Editora Gazeta Santa Cruz, 140p.

Brito, R.A.S., Cavalcante, G.P., Maffia, L.A., 2014. Selective isolating of Ceratocystis fimbriata. Phytopathology 104 (11), 19.

Carvalho, C.R.L., Rossetto, C.J., Mantovani, D.M.B., Morgano, M.A., Castro, J.D., Bortoletto, N., 2004. Avaliação de cultivares de mangueira selecionadas pelo instituto agronômico de campinas comparadas a outras de importância comercial. Rev. Bras. Frutic. 26 (2), 264-271.

Carvalho, M., 1938. Sobre dois insetos nocivos à mangueira. Boletim da Secretaria da Agricultura Indústria e Comércio do Estado de Pernambuco 3 (2), 130-132.

FAO, 2013. FAOSTAT. Food and Agriculture Organization of the United Nations, accessed in: 20.07.15.

Galli, J.A., Martins, A.L.M., Ito, M.F., Braghini, M.T., Narita, N., Rossetto, C.J., 2011. Seca-da-mangueira XXII. sobrevivência de variedades poliembriônicas. Rev. Bras. Frutic. 33 (4), 1119-1126.

Iyer, C.P.A., Schnell, R.J., 2009. Breeding and Genetics. In: Litz, R. E. (Ed). The Mango: Botany, Production and Uses, 67-96.

Knight Jr., R.J., Campbell, R.J., Maguire, I., 2009. Important Mango Cultivars and their Descriptors. In: Litz, R.E. (Ed). The Mango: Botany, Production and Uses, 43-66.

Malik, M.T., Khan, S.M., Dasti, A.A., Kazmi, M.R., 2005. First record of Ceratocystis fimbriata, causal organism of mango sudden death in Pakistan. Pak. J. Phytopathol. 17, 187-191.

Masood, A., Saeed, S., Sajjad, A., 2008. Characterization and damage patterns of different bark beetle species. Pak. Entomol. 30 (2), 163-168.

Mukherjee, S.K., Litz, R.E., 2009. Introduction: Botany and Importance. In: Litz, R. E. (Ed). The Mango: Botany, Production and Uses, 1-18.

Mukherjee, S.K., 1972. Origin of mango (Mangifera indica). Econ. Bot. 26 (3), 260-264.

Nunes, A.S., 2015. Resistência de mangueira Ubá (Mangifera indica) à murcha-de ceratocystis (Ceratocystis fimbriata). Dissertação de mestrado, Universidade Federal de Viçosa, Brasil, pp. 27.

Oliveira, L.S.S., Harrington, T.C., Ferreira, M.A., Damacena, M.B., Al-Sadi, A.M., Al Mahmooli, I.H.S., Alfenas, A.C., 2015a. Species or genotypes? Reassessment of four recently described species of the Ceratocystis wilt pathogen, C. fimbriata, on Mangifera indica. Phytopathology 105 (9), 1229-1244.

Oliveira, L.S.S., Guimarães, L.M.S., Ferreira, M.A., Nunes, A.S., Pimenta, L.V.A., Alfenas, A.C., 2015b. Aggressiveness, cultural characteristics and genetic variation of Ceratocystis fimbriata on Eucalyptus spp. For. Pathol. Online.

Oliveira, L.S.S., Damacena, M.B., Guimarães, L.M.S., Siqueira, D.L., Alfenas, A.C., 2016. Isolates of Ceratocystis fimbriata from Mangifera indica have different levels of aggressiveness. Eur. J. Plant Pathol., 1-10.

Ploetz, R.C., Freeman, S., 2009. Foliar, Floral and Soilborne Diseases. In: Litz, R. E. (Ed). The Mango: Botany, Production and Uses, 232-302.

Resende, M.D.V., Duarte, J.B., 2007. Precisão e controle de qualidade em experimentos de avaliação de cultivares. Pesqui. Agropecu. Trop. 37 (3), 182-194.

Resende, M.D.V., 2002. Software SELEGEN-REML/BLUP. 67.

Resende, M.D.V., 2007. Matemática e estatística na análise de experimentos e no melhoramento genético. Embrapa Florestas, Colombo, pp. 435

Ribeiro, I.J.A., Lourenção, A.L., Pilho, O.P., Soares, N.B., 1984. Seca da mangueira: VII. Resistência de cultivares de mangueira ao fungo Ceratocystis fimbriata Ell. \& Halst. Bragantia 43 (1), 237-243.

Ribeiro, I.J.A., Rossetto, C.J., Sabino, J.C., Gallo, P.B., 1986. Seca da mangueira: VIII. Resistência de porta-enxertos de mangueira ao fungo Ceratocystis fimbriata Ell. \& Halst. Bragantia 45 (2), 317-322.

Rocha, A., Salomão, T.M.F., Siqueira, D.L., Cruz, C.D., Salomão, L.C.C., 2014 Identification of Ubá mango tree zygotic and nucellar seedlings using ISSR markers. Revista Ceres 61 (5), 597-604.

Rosado, C.C.G., Guimarães, L.M.S., Titon, M., Douglas, L., Rosse, L., Resende, M.D.V Alfenas, A.C., 2010. Resistance to ceratocystis wilt (Ceratocystis fimbriata) in parents and progenies of Eucalyptus grandis $\times$ E. urophylla. Silvae Genetica 3, 99-106.

Rossetto, C.J., Ribeiro, I.J.A., 1983. Seca da Mangueira VI. Uma revisão do problema. Ciência e Cultura 35 (10), 1411-1415. 
Rossetto, C.J., Ribeiro, IJ.A., Igue, T., Gallo, P.B., 1996. Seca da mangueira XV. Resistência varietal a dois isolados de Ceratocystis fimbriata. Bragantia 55 (1), 117-121.

Roux, J., Dunlop, R., Wingfield, M.J., 2000. Development of disease tolerant Acacia mearnsii. In: Forest Genetics for the Next Millennium. Proceedings of IUFRO Working Party 2.08. 01 Conference, 8-13 October 2000, Durban, pp. 200-202.

Schnell, R., Brown, J.S., Olano, C., Meerow, A., Campbell, R., Kuhn, D., 2006. Mango genetic diversity analysis and pedigree inference for Florida cultivars using microsatellite markers. Hortscience 41 (4), 993.
Souza, A.G.C., Maffia, L.A., Murta, H.M., Alves, Y.H., Pereira, R.M., Picanso, M.C. 2013. First report on the association between Ceratocystis fimbriata, an agent of mango wilt, Xyleborus affinis, and the sawdust produced during beetle volonization in Brazil. Plant Dis. 97 (8), 1116.

Van Wyk, M., Al Adawi, A.O., Khan, I.A., Deadman, M.L., Jahwari, A.A.A., Wingfield, B.D., Ploetz, R., Wingfield, M.J., 2007. Ceratocystis manginecans sp. nov.: causal agent of a destructive mango wilt disease in Oman and Pakistan. Fungal Divers. 27, 213-230.

Viegas, A.P., 1960. Mango blight. Bragantia 19, 163-182. 